
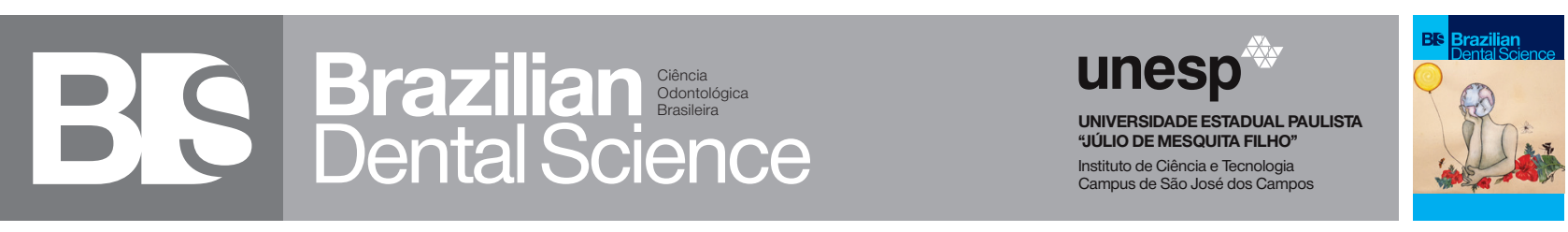

\title{
Mutans streptococci growth on glass ionomer incorporated with chlorhexidine: in-vivo study
}

\author{
Crescimento de Estreptococos mutans em ionômero de vidro incorporado com clorexidina: estudo in vivo \\ Basem M ABUZENADA ${ }^{1,2}$, Yasser R SOUROR ${ }^{2,3}$, Ahmed S WALY ${ }^{3,4}$, Yousef H. Abo KHLIFA \\ 1 - Department of Operative Dentistry - King Abdul-Aziz University - Jeddah - Makkah - Saudi Arabia. \\ 2 - Batterjee Medical College - Jeddah - Saudi Arabia. \\ 3 - Faculty of Dentistry - Alazhar University - Assuit - Egypt. \\ 4 - AlFarabi Dental College - Jeddah - Saudi Arabia. \\ 5 - Faculty of Dentistry - Alazhar University - Cairo - Egypt.
}

\begin{abstract}
Background: glass ionomer is one of the most frequently used restorative materials for primary teeth restoration. It has been in use for more than 30 years. Their restoration usefulness is preferential compared to other restorations due to their fluoride release and recharge, chemical adhesion to the structure of the dentin and their range of uses. Increasing the antibacterial efficacy of restorative materials is one of the primary goals to decrease the incidence of recurrent caries. Chlorhexidine is the gold standard antibacterial agent in dentistry. Objectives: the objective of this study is to evaluate the antibacterial effect of Chlorhexidine incorporated with glass ionomer on Streptococcus mutans. Methods: Thirty Children between ages ranged 6-9 years old were selected to participate in this study. Children with bilateral caries in lower second primary molars affecting the occlusal and proximal surfaces without pulpitis were included in the study. All cavities were divided into two groups; group (A) restored with Glass Ionomer and group (B) restored with Glass Ionomer Chlorhexidine mixture. The sound proximal surfaces in all cavitated teeth acted as a control. After one month, two months and three months' plaque samples were obtained and Streptococcus mutans counts were calculated. Results: The number of SM taken from sound proximal surfaces for all groups were not changed significantly in whole periods of study. At the all-time interval, the mean log10 of SM in group B was lower than group A and the difference was statistically significant. There is a significant difference in the mean $\log 10$ of SM in group B between the 1St month and the 3rd month. Conclusion: The growth of SM was found to be higher in the sound tooth than in GI groups and in GI group was higher than in CHX- GI mixture up to three months.
\end{abstract}

\section{KEYWORDS}

Chlorhexidine; Glass Ionomer; Streptococcus mutans.

\section{RESUMO}

Antecedentes: o ionômero de vidro é um dos materiais restauradores mais utilizados na restauração de dentes decíduos. É usado há mais de 30 anos. Sua indicação como material restaurador em comparação a outros baseia-se nas propriedades de liberação e recarga de flúor, adesão química à estrutura da dentina e sua variedade de usos. Aumentar a eficácia antibacteriana de materiais restauradores é um dos principais objetivos para diminuir a incidência de cárie recorrente. A clorexidina é o agente antibacteriano padrão-ouro em odontologia. Objetivos: o objetivo deste estudo é avaliar o efeito antibacteriano da Clorexidina incorporada ao ionômero de vidro no Streptococcus mutans (SM). Métodos: Trinta crianças entre 6 e 9 anos foram selecionadas para participar deste estudo. Crianças com cárie bilateral nos segundos molares decíduos inferiores que afetavam as superfícies oclusal e proximal sem pulpite foram incluídas no estudo. Todas as cavidades foram divididas em dois grupos; grupo A, restaurado com Ionômero de Vidro e grupo B, restaurado com mistura de Ionômero de Vidro/Clorhexidina. As superfícies proximais sadias em todos os dentes cavitados atuavam como controle. Após um mês, dois e três meses, foram obtidas amostras de placa e as contagens de Streptococcus mutans foram realizadas. Resultados: O número de SM retirado da superfície proximal sadia para todos os grupos não foi alterado significativamente nos períodos do estudo. No intervalo de todos os tempos, o $\log 10$ médio da SM no grupo B foi menor que no A e a diferença foi estatisticamente significante. Há uma diferença significativa no $\log 10$ médio da SM no grupo B entre o $1^{\circ}$ mês e o $3^{\circ}$ mês. Conclusão: O crescimento da SM mostrou-se maior no dente sadio do que nos grupos A; e no grupo A foi maior que no grupo B até três meses.

\section{PALAVRAS-CHAVE}

Clorexidina; Ionômero de vidro; Streptococcus mutans. 


\section{INTRODUCTION}

$\mathrm{M}$ any studies and documents have concluded caries lesions that develop around restorations are the most commonly reported reason for restoration replacement in primary teeth, especially when there is no compliance as child patient [1-4].

Recurrent caries was the basis to the extent of the cavo-surface margin to a selfcleansable location where the toothbrush might have had access to the plaque. Since the only recognized way to prevent caries at that time was tooth brushing [5].

Caries lesion mostly was seen on the proximal surface of the primary teeth, where the caries progression in this area seems to be faster than on occlusal surfaces [6-7].

Streptococcus mutans are essential for the initiation and advancement of caries, and lactobacillus acidophilus is frequently present in superficial and deep caries in large numbers. Streptococcus mutans and Lactobacillus acidophilus are often considered as the two most important cariogenic bacteria associated with dentine caries [8].

The ability of restorative material to resist secondary caries attack and microleakage at its margins can be achieved by the improvement of restorative material properties and will largely determine whether restoration will succeed or fail [9].

In the last century, many new modern filling products have been created to be resistant to secondary caries as it has shown some antimicrobial activity, The most significant thing is their potential to release fluoride and bind with the prepared tooth surface $[10,11]$.

There is moderate strength of evidence for a positive association between Glass ionomer and the prevention of caries lesions only in the margins of occluso-proximal restorations of primary teeth [12].

Chlorhexidine is a strong antiplaque agent that also has an outstanding antimicrobial property. It is a wide antimicrobial spectrum and can be regarded as a boon to maintaining oral health as a whole. As well it has been shown to control the decay of the tooth with promising outcomes. It is efficient against a wide range of Gram-positive bacteria, Gramnegative bacteria and fungi [13-15].

Because of its enhanced susceptibility relative to other oral microorganisms, chlorhexidine is one of the most appropriate efficient and secure agents in decreasing Streptococcus mutans [16].

Several researches have shown that adding chlorhexidine to a glass ionomer has resulted in a regeneration that has improved its antibacterial characteristics over glass ionomers alone [17-22].

In the present study, the effect of Chlorhexidine on the growth of Streptococcus mutans when added to the Glass Ionomer was evaluated.

\section{MATERIAL AND METHODS}

Thirty Children between ages ranged 6-9 years old were selected to participate in this study from Outpatient Clinic in Pediatric Dentistry Department, Faculty of Dentistry, Assuit dental College; Assuit Egypt. Children with bilateral caries in lower second primary molars affecting the occlusal and proximal surfaces without pulpitis were included in the study. A consent form was signed by the children's parents before the study. Complete medical and dental history was obtained for each of the selected children and was subjected to cavity preparation then restoration.

\section{Restoration}

All cavities were divided into two groups:

Group A: cavities in right second primary molars were restored by Fuji II LC (GC America Inc.) glass ionomer.

Group B: cavities in left second primary molars were restored by Chlorhexidine- Glass Ionomer Fuji II LC. 
Preparation of Chlorhexidine Glass Ionomer mixture was performed by adding $0.01 \mathrm{ml}$ of chlorhexidine gel 2\% Gluco-CHeX (PPH Cerkamed, Stalowa Wola, Poland) to resin-modified glass ionomer capsule which contains $0.10 \mathrm{ml}$ net volume of mixed cement after dispensing on cleaned sterilized glass slap. The mixture was loaded to the cavity after cleaning the cavity with distilled water then dried with air for 10 seconds All restorations were cured for 30 seconds according to manufacture instructions.

All children received general oral hygiene instructions and were oriented to brush their teeth 3 times a day after meals using a toothbrush and a fluoride-containing dentifrice supplied by the researchers throughout the experimental period. No other fluoride sources were used.

\section{Microbiological analysis}

After one month the plaque samples were pooled by sterilized toothpick hold by sterilized hemostat. Before the sample had been taken the whole surface of the tooth washed with water and air-dried for 10 seconds. The tip of the toothpick was holed toward proximal surfaces between filling material and enamel for 10 seconds (A1 or B1 subgroups), and the tip of another toothpick was holed toward sound proximal surfaces in restored molars (A2 or B2 subgroups) [23].

The procedure was repeated at the interval of two months, and three months. Colonies with mutans streptococci (MS) characteristics were transferred to tubes containing thioglycollate (Difco Laboratories Inc., Detroit, MI, USA) and incubated at $37^{\circ}$ $\mathrm{C}$ for $24 \mathrm{~h}$ for biotyping. The growth of MS colony-forming unit (CUF) was verified after the incubation period, and the following tests were performed for biochemical identification: fermentation of mannitol, sorbitol, raffinose and melibiose, resistance to bacitracin, hydrolysis of arginine and sculin, production of $\mathrm{H}_{2} \mathrm{O}_{2}$, and sensitivity to $2.0 \mathrm{IU}$ bacitracin. Biofilm samples were spread on $15 \times 100 \mathrm{~mm}$ sterile test tubes containing 4 to 5 glass beads and $2.0 \mathrm{~mL}$ phosphate buffer saline (PBS). biofilm samples were vortexed for 2 and $1 \mathrm{~min}$, respectively, for microbial desorption, and submitted to ten-fold serial dilutions $\left(10^{-5}\right)$. After that, $50 \mathrm{~mL}$ of each dilution was plated equidistantly on the SB-20M culture medium and incubated under the candle jar system at $37^{\circ} \mathrm{C}$ for 48 to 72 hours. The number of (CFU) per milliliter of biofilm was counted, and biotyping of colonies with MS characteristics were performed, the Streptococcus mutans colony-forming units (CFU) were done by standard, or viable, plate count method [24]. At the end of the incubation period, all of the Petri plates containing between 30 and 300 colonies were selected. The colonies on each plate were counted. A Quebec colony counter was used. (CFU) per milliliter was calculated by dividing the number of colonies by the dilution factor multiplied by the amount of specimen. The original data measured in CFU were transformed in $\log 10$ for statistical analysis and are reported as $\log (\mathrm{CFU}) / \mathrm{ml}$.

\section{Statistical methods}

SPSS version 12.0 was used for data management and data analysis. Streptococcus mutans counts were transformed to log values to be normally distributed (avoid high variability). The analysis was done on $\log$ values and description was made by the mean and standard deviation. Repeated measures ANOVA was done to elicit time effect within each group and to verify if there is any difference in the rate of drop of bacterial count over time between the two groups what is called time and group interaction. Chi-square and Fisher's exact test was used for comparing proportions among 2 study groups. P-value is significant at 0.05 levels.

\section{RESULTS}

This in vivo study was conducted to evaluate the growth of Streptococcus mutans on resin-modified Glass Ionomer restorative material and chlorhexidine-glass Ionomer 
mixture. Plaque samples were collected from;

The proximal surface of GI only restorations (group A1), $(\mathrm{n}=30)$.

The sound proximal surfaces of teeth restored with GI only (group A2), ( $=30)$.

The proximal surfaces of teeth restored with GI CHX mixture (group B1), (n=30).

The sound proximal surfaces of teeth restored with GI CHX mixture (group B2) (n $=30)$.

The samples from the sound proximal surface act as a control for both groups.

The number of SM taken from sound proximal surfaces for both groups (A2 and B2) were not changed significantly in whole periods of study (Table I).

The mean $\log _{10}$ of SM on GI (Group A1) was higher than the mean $\log _{10}$ of SM on GI with CHX (Group B1) after one month, two months and three months and the difference was found to be statistically significant (Tables II).

In group A: After one, two and three months the mean $\log _{10}$ of SM in group A1 was lower than in group A2 and the difference was statistically significant (Table III).

There is no significant difference in the mean $\log _{10}$ of SM in group A1 between the $1^{\text {St }}$ month and the second month and between the $1^{\text {st }}$ month and the $3^{\text {rd }}$ month (Table IV).

In group B: After one, two and three months the mean $\log _{10}$ of SM in group B1 was lower than in group B2 and the difference was statistically significant (Table V)

There is no significant difference in the mean $\log _{10}$ of SM in group B1 between the $1^{\text {St }}$ month and the second month, however, the difference was significate when comparing the $1^{\text {st }}$ month with the $3^{\text {rd }}$ month (Table VI) .
Table I - The mean, standard deviation (SD) values and results of paired t-test for comparison between $\log _{10} \mathrm{SM}$ in sound proximal surfaces for both groups

\begin{tabular}{|c|c|c|c|c|c|}
\hline Side & \multicolumn{2}{|c|}{ Group A2 $(n=30)$} & \multicolumn{2}{|c|}{ Group B2(n=30) } & \multirow{2}{*}{$P$-value } \\
\hline Period & Mean $\log _{10}$ & SD & Mean $\log _{10}$ & SD & \\
\hline 1month & 4.51 & 0.04 & 4.52 & 0.02 & 0.3236 \\
\hline 2 months & 4.52 & 0.01 & 4.51 & 0.02 & 0.0527 \\
\hline 3 months & 4.51 & 0.02 & 4.51 & 0.01 & 1.0000 \\
\hline
\end{tabular}

*: Significant at $P \leq 0.05$

Table II - The mean, standard deviation (SD) values and results of paired t-test for comparison between $\log _{10} S M$ in group $A 1$ and Group B1

\begin{tabular}{|c|c|c|c|c|c|}
\hline 0 & \multicolumn{2}{|c|}{ A1 GI $(n=30)$} & \multicolumn{2}{|c|}{ B1 CHX (n=30) } & \multirow{2}{*}{$\boldsymbol{P}$-value } \\
\hline Period & Mean $\log _{10}$ & SD & Mean $\log _{10}$ & SD & \\
\hline 1month & 4.05 & 0.04 & 3.34 & 0.09 & $<0.001^{\star}$ \\
\hline 2 months & 4.06 & 0.01 & 3.54 & 0.05 & $<0.001^{*}$ \\
\hline 3 months & 4.06 & 0.03 & 3.77 & 0.07 & $<0.001^{\star}$ \\
\hline
\end{tabular}

*: Significant at $P \leq 0.05$

Table III - The mean, standard deviation (SD) values and results of paired t-test for comparison between $\log _{10} S M$ in group $A 1$ and Group A2 at different periods

\begin{tabular}{ccccccc}
\hline Side & \multicolumn{2}{c}{ A1 Gl $(n=30)$} & \multicolumn{2}{c}{ A2 $(n=30)$} & P-value \\
Period & Mean $\log _{10}$ & SD & Mean $\log _{10}$ & SD & \\
\hline 1month & 4.05 & 0.04 & 4.51 & 0.04 & $<0.0001$ \\
2months & 4.06 & 0.01 & 4.52 & 0.01 & $<0.0001$ \\
3months & 4.06 & 0.03 & 4.51 & 0.02 & $<0.0001$ \\
\hline
\end{tabular}

*: Significant at $P \leq 0.05$

Table IV - The mean, standard deviation (SD) values and results of paired t-test for comparison between $\log _{10} \mathrm{SM}$ in group $\mathrm{A} 1$ at different periods

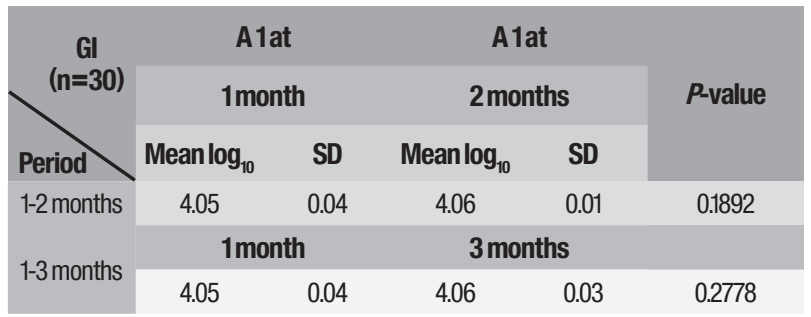

*: Significant at $P \leq 0.05$ 
Table V - The mean, standard deviation (SD) values and results of paired t-test for comparison between $\log _{10} \mathrm{SM}$ in group B1 and Group B2 at different periods

\begin{tabular}{|c|c|c|c|c|c|}
\hline cirn & \multicolumn{2}{|c|}{ Group B1 $(n=30)$} & \multicolumn{2}{|c|}{ Group B2 $(n=30)$} & \multirow{2}{*}{$P$-value } \\
\hline Period & Mean $\log _{10}$ & SD & Mean $\log _{10}$ & SD & \\
\hline 1month & 3.34 & 0.09 & 4.52 & 0.02 & $<0.0001$ \\
\hline 2 months & 3.54 & 0.05 & 4.51 & 0.02 & $<0.0001$ \\
\hline 3 months & 3.77 & 0.07 & 4.51 & 0.01 & $<0.0001$ \\
\hline
\end{tabular}

*: Significant at $P \leq 0.05$

Table VI - The mean, standard deviation (SD) values and results of paired t-test for comparison between $\log _{10} S M$ in group B 1 at different periods

\begin{tabular}{|c|c|c|c|c|c|}
\hline \multirow{3}{*}{$\begin{array}{c}\text { CHX } \\
(n=30)\end{array}$} & \multicolumn{2}{|c|}{ B1at } & \multicolumn{2}{|c|}{ B1at } & \multirow{3}{*}{$P$-value } \\
\hline & \multicolumn{2}{|c|}{ 1month } & \multicolumn{2}{|c|}{2 months } & \\
\hline & Mean $\log _{10}$ & SD & Mean $\log _{10}$ & SD & \\
\hline 1-2 months & 3.34 & 0.09 & 3.54 & 0.5 & 0.0352 \\
\hline \multirow{2}{*}{$1-3$ months } & \multicolumn{2}{|c|}{ 1month } & \multicolumn{2}{|c|}{3 months } & \\
\hline & 3.34 & 0.09 & 3.77 & 0.07 & $<0.0001$ \\
\hline
\end{tabular}

*: Significant at $P \leq 0.05$

\section{DISCUSSION}

The present study was carried out to comparetheStreptococcusmutans accumulation on Glass Ionomer that had been modified by the addition of chlorohexidine with Glass Ionomer alone used for cavity restoration. and did the addition of chlorohexidine result in a restorative material that had increased antibacterial properties over light-cured glassionomer alone.

It is well known that dental caries is bacterially based diseases. Dental bio-film is a significant factor in the incidence of dental caries that includes complicated structures composed of various microbial multi-species groups created on oral tissue. Tooth decay is primarily obtained from carcinogenic (particularly streptococci) organisms that engage in biofilm formation and produce subsequent cariogenesis. [25] Streptococcus mutans and other cariogenic bacteria may enter the GIC-dentin interfaces via microleakage at the tooth restoration interface to cause secondary caries, resulting in GIC loss and substitution [26].

The present study was carried out by the split-mouth technique where the Glass Ionomer-Chlorhexidine mixture was employed as a restorative material for carious primary molars on one side of selected children, while the conventional Glass Ionomer was used for carious primary molars in the other side of the same arch.

The most frequently cited cause for replacing the restoration was caries that developed around restorations which are more common in primary teeth, especially when there is no compliance as child patient. Primary molars have therefore been chosen in this research. [1-4]

While most caries lesions occur on the proximal surface in primary molars and caries progression in this area appears to be faster than on occlusal surfaces,6,7so in this these surfaces were selected in this study.

All children's parents were instructed to prevent their children from using any product containing chlorohexidine during the waiting time between visits so the only source for chlorohexidine around the restoration was from the modified glass ionomer to exclude any external effect.

It was designed as a split-mouth study to exclude the influence of individual patient characteristics and to obtain a more powerful estimate of treatment effect with smaller sample size. In oral health studies, the splitmouth design is common $[27,28]$.

The present study showed that SM count was almost constant in all control samples from both groups (A2, B2) through all period of examination, in GI group; (group A1) SM count was slightly decreased than in control samples (A2) all period of examination which is statically significant but difference was statistically insignificant in the same group (A1) between one month, two months and three months. The possible explanation is 
that the Higher levels of fluoride release were observed on the first day, decreasing rapidly in the second and third days, and decreasing gradually in the following days until a constant level of fluoride -release was reached [29].

After one-month, the SM count in group (B1) was less than SM count in group (A 1) and in control samples and this difference was statistically significant. as the control restoration was included with the tested restoration in the same oral cavity so the effect of adding chlorhexidine was clear.

The decreased antibacterial effect of CHX with time may be due to elution which might result in material loss or as a result of the formation of insoluble salts with the glass-ionomer which suggested by Ribeiro and Ericson (1991) [8]. On the other hand, secondary caries may be prevented for a long time that's because the microenvironment of the restoration still has a sufficient level of CHX.

However, Forss $\mathrm{H}$ et al found that the fluoride concentration of plaque on or adjacent to glass ionomers is increased and the percentage of plaque mutans streptococci decreases even after one month [30].

On the other hand, several clinical studies showed that the fluoride concentrations released in vivo from old GI and RMGI are not high enough to affect the plaque levels of the caries-associated bacteria mutans streptococci and suggested that the antimicrobial activity occurs only in the initial phase and is not responsible for a long-term anti-cariogenic property [31-33].

Chlorhexidine is well known antibacterial agent and the short term clinical study by Mishra et al. examined the mixture of glass ionomer - chlorhexidine suggested that a significant increase in antibacterial effect of the mixture than glass ionomer alone [34].

However long term in vitro study claimed that chlorhexidine gluconate $2.5 \%$ showed great antibacterial activity up to 30 days and significantly decreased after 50 days [35].
Bellis et al investigated the long-term release of soluble chlorhexidine added to glass ionomer and found that the addition of a GIC with CHX paste resulted in cement releasing soluble chlorhexidine in a dosedependent manner for more than 14 months. He used sustained-release CHX chlorhexidinehexametaphosphate instead of CHX gluconate used in the current study [36].

After two and three months SM count in group (B1) was less than SM count in group (A1) and in control samples and this difference was statistically insignificant.

The results of our study were in accordance with Huiyi Yan et al. [37] who tested the antibacterial effect of the Glass Ionomer - Chlorhexidine mixture and concluded that CHX was continuously released, and antibiofilm ability was maintained up to 30 days.

\section{CONCLUSIONS}

Incorporation of $\mathrm{CHX}$ to GI filling material may decrease SM growth than GI alone for up to three months.

\section{REFERENCES}

1. Mjör IA, Jokstad A, Qvist V. Longevity of posterior restorations. Int Dent J. 1990 Feb;40(1):11-7.

2. Jokstad A, Bayne S, Blunck U, Tyas M, Wilson N. Quality of dental restorations. FDI Commission Project2-95. Int Dent J. 2001 Jun;51(3):117-58.

3. Demarco FF, Corrêa MB, Cenci MS, Moraes RR, Opdam NJ.Longevity of posterior composite restorations: not only a matter of materials. Dent Mater. 2012 Jan;28(1):87-101. doi: 10.1016/j.dental.2011.09.003.

4. HickelR, Kaaden C, PaschosE, Buerkle V, García-Godoy F, Manhart J.Longevity of occlusally-stressed restorations in posterior primary teeth. Am J Dent. 2005 Jun;18(3):198-211.

5. Black GV.A work on operative dentistry. Chicago: Medico-Dental Publishing; 1908. (The technical procedures in filling teeth,2)

6. Ripa LW, Leske GS. Two years' effect on the primary dentition of mouth rinsing with a $0.2 \%$ neutral NaF solution. Community Dent Oral Epidemiol. 1979 Jun;7(3):151-3.

7. Vanderas AP,Manetas C, Koulatzidou M, Papagiannoulis L. Progression of proximal caries in the mixed dentition: a 4-year prospective study. Pediatr Dent.2003 May-Jun;25(3):229-34.

8. Mei ML, Chu CH, Low KH, Che CM, Lo EC. Caries arresting effect of silver diamine fluoride on dentine carious lesion with $S$. mutans and L. acidophilus dual-species cariogenic biofilm. Med Oral Patol Oral Cir Bucal. 2013 Nov 1;18(6):e824-31.

9. Naik NS, Subba Reddy VV, Shashikiran ND. Comparative evaluation of secondary caries formation around light-cured fluoride-releasing restorative materials. J Indian Soc Pedod Prev Dent. 2017 Jan-Mar;35(1):75-82 doi:10.4103/0970-4388.199235. 
10. Al-Sabri FA, El-Marakby AM, Mossa H. Glass lonomer Cement Release of the Fluoride as Anti-Cariogenic Properties among Four Different Types. Comparative Evaluation. EC Dental Sci. 2017;7(5):185-92.

11. KucukyilmazE, Savas S, Kavrik F, Yasa B, Botsali MS. Fluoride release/ recharging ability and bond strength of glass ionomer cements to sound and caries-affected dentin. Niger J Clin Pract.2017 Feb;20(2):226-34. doi: 10.4103/1119-3077.178917

12. Raggio DP,Tedesco TK, Calvo AF,Braga MM. Do glass ionomer cements prevent caries lesions in margins of restorations in primary teeth?:A systematic review and meta-analysis. J Am Dent Assoc. 2016 Mar;147(3):17785. doi:10.1016/j.adaj.2015.09.016

13. Sajjan P,Laxminarayan N, Kar PP,Sajjanar R. Chlorhexidine as an antimicrobial agent in dentistry: a review. OHDM 2016;15(2):93-100.

14. Guneser MB, Akbulut MB, Eldeniz AU. Antibacterial effect of chlorhexidinecetrimide combination, Salvia officinalis plant extract and octenidine in comparison with conventional endodontic irrigants. Dent Mater J. 2016;35(5):736-41

15. Peedikayil FC, Remy V, JohnS, Chandru TP,Sreenivasan P,Bijapur GA.Comparison of antibacterial efficacy of coconut oil and chlorhexidine on Streptococcus mutans: An in vivo study. J Int Soc Prev Community Dent. 2016 Sep-0ct;6(5):447-52.

16. Emilson CG. Susceptibility of various microorganisms to chlorhexidine. Scand J DentRes. 1977 May;85(4):255-65. doi:10.1111/.j1600-0722.1977.tb00561.x.

17. Sanders BJ, Gregory RL, Moore K, Avery DR. Antibacterial and physical properties of resin modified glass-ionomers combined with chlorhexidine.J Oral Rehabil. 2002 Jun;29(6):553-8.

18. Hoszek A, Ericson D. In vitro fluoride release and the antibacterial effect of glass ionomers containing chlorhexidine gluconate. Oper Dent. 2008 NovDec;33(6):696-701. doi:10.2341/08-20.

19. Cheng L, Weir MD, Xu HH, Kraigsley AM, Lin NJ, Lin-Gibson S, Zhou X. Antibacterial and physical properties of calcium-phosphate and calciumfluoride nanocomposites with chlorhexidine. Dent Mater.2012 May;28(5):57383. doi:10.1016/.dental.2012.01.006.

20. Palmer G, Jones FH, Billington RW, Pearson GJ. Chlorhexidine release from na experimental glass ionomer cement. Biomaterials. 2004 0ct;25(23):5423-31.

21. Lim BS, Cheng Y, Lee SP,Ahn SJ.Chlorhexidine release from orthodontic adhesives after topical chlorhexidine treatment. Eur J Oral Sci. 2013 Jun;121(3 Pt1):211-7.doi: 10.1111/eos.12033.

22. Hook ER, Owen OJ, Bellis CA, Holder JA, O'Sullivan DJ, Barbour ME Development of a novel antimicrobial-releasing glass ionomer cement functionalized with chlorhexidine hexametaphosphate nanoparticles. J Nanobiotechnology.2014 Jan 23;12:3. doi:10.1186/1477-3155-12-3

23. Wennerholm K, Lindquist B, Emilson CG. The toothpick method in relation to other plaque sampling techniques for evaluating mutans streptococci. Eur $J$ Oral Sci. 1995 Feb;103(1):36-41.

24. Davey HM. Life, death, and in-between: meanings and methods in microbiology Appl Environ Microbiol. 2011 Aug 15;77(16):5571-6. doi:10.1128/AEM.00744-11
25. Islam B, Khan SN, Khan AU. Dental caries: from infection to prevention. Med Sci Monit. 2007 Nov;13(11):RA196-203.

26. Klai S, Altenburger M, Spitzmüller B, Anderson A, Hellwig E, Al-Ahmad A. Antimicrobial effects of dental luting glass ionomer cements on Streptococcus mutans. Scientific World Journal. 2014 Mar 23:2014:807086. doi:10.1155/2014/807086.

27. Hujoel PP,DeRouen TA. Validity issues in split-mouth trials. J Clin Periodontol. 19920ct;19(9Pt1):625-7.

28. Lesaffre E Philstrom B, Needleman I, Worthington $H$. The design and analysis of split-mouth studies: what statisticians and clinicians should know. Stat Med. 2009 Dec 10;28(28):3470-82. doi: 10.1002/sim.3634

29. Dasgupta S, Saraswathi MV, Somayaji K, Pentapati KC, Shetty P.Comparative evaluation of fluoride release and recharge potential of novel and traditional fluoride-releasing restorative materials: An in vitro study.J Conserv Dent. 2018 Nov-Dec;21(6):622-626. doi:10.4103/JCD.JCD 338 18.

30. Forss H, Jokinen J, Spets-Happonen S, SeppäL, Luoma H. Fluoride and mutans streptococci in plaque grown on glass ionomer and composite. Caries Res.1991;25(6):454-8.

31. Mota SM, EnokiC, Ito IY, Elias AM, Matsumoto MA. Streptococcus mutans counts in plaque adjacent to orthodontic brackets bonded with resin-modified glass ionomer cement or resin-based composite. Braz Oral Res. 2008 JanMar;22(1):55-60

32. Andrucioli MC, Faria G, Nelson-Filho P,Romano FL, Matsumoto MA. Influence of resin-modified glass ionomer and topical fluoride on levels of Streptococcus mutans in saliva and biofilm adjacent to metallic brackets. J Appl Oral Sci. 2017 Mar-Apr;25(2):196-202

33. Mittal S, Soni H, Sharma DK, Mittal K, Pathania V, Sharma S. Comparative evaluation of the antibacterial and physical properties of conventional glass ionomer cement containing chlorhexidine and antibiotics. J Int Soc Prev Community Dent.2015 Jul-Aug;5(4):268-75. doi: 10.4103/2231-0762.161754.

34. Mishra A, Pandey RK, Manickam N. Antibacterial effect and physical properties of chitosan and chlorhexidine-cetrimide-modified glass ionomer cements. J Indian Soc Pedod Prev Dent. 2017 Jan-Mar;35(1):28-33.

35. Türkün LS, Türkün M, Ertuğrul F, Ateş M, Brugger S. Long-Term Antibacterial Effects and Physical Properties of a Chlorhexidine-Containing Glass lonomer Cement. J Esthet Restor Dent. 2008;20(1):29-44.

36. Bellis CA, Nobbs AH, O'Sullivan DJ, Holder JA, Barbour ME. Glass ionomer cements functionalised with a concentrated paste of chlorhexidine hexametaphosphate provides dose-dependent chlorhexidine release over at least 14 months. J Dent. 2016 Feb;45:53-8. doi: 10.1016/j.jdent.2015.12.009

37. Yan H, Yang H, LiK, Yu J, Huang C. Effects of Chlorhexidine-Encapsulated Mesoporous Silica Nanoparticles on the Anti-Biofilm and Mechanical Properties of Glass lonomer Cement. Molecules. 2017 Jul 21,22(7). pii::E1225. doi:10.3390/molecules22071225.

\section{Yasser R Souror}

(Corresponding address)

Department of Pediatric Dentistry and Dental Public Health, Faculty of Dental Medicine. Al-Azhar University, Assiut Branch. Egypt P.O Box 71511

Head of Pediatric Dentistry Department, Batterjee Medical College, Saudi Arabia.

P.O. Box 6231, Jeddah 21442

Date submitted: 2019 0ct 16

E-mail: doctoryaser@gmail.com Accept submission: 2020 Jan 28 